DOI https://doi.org/10.15589/znp2020.4(482).6

УДК 62-6

\title{
LOW-POWER INDUCTION HEATING SYSTEMS POWER SUPPLY DESIGN FEATURES
}

\section{ОСОБЛИВОСТІ ПРОЄКТУВАННЯ ДЖЕРЕЛ ЖИВЛЕННЯ МАЛОПОТУЖНИХ УСТАНОВОК ІНДУКЦЙНОГО НАГРІВУ}

\author{
Dmitry V. Kostenko \\ dmi.kostenko@gmail.com \\ ORCID: 0000-0003-2251-6932 \\ Serhii L. Trybulkevich \\ sergiy.trybulkevich@nuos.edu.ua \\ ORCID: 0000-0001-5783-6616
}

\author{
Д. В. Костенко, \\ канд. техн. наук, доцент \\ С. Л. Трибулькевич, \\ старший викладач
}

\author{
Admiral Makarov National University of Shipbuilding, Mykolaiv \\ Наиіональний університет кораблебудування імені адмірала Макарова, м. Миколаїв
}

\begin{abstract}
The principles of construction of power supplies of induction heating installations are analyzed. The main circuit solutions for the construction of the power part, such as bridge and semi-bridge inverter, are considered. A review of modern experience in the practical manufacture of induction heating systems and their power supplies. The main problems that arise when designing high-frequency power supplies based on MOSFET and IGBT transistors are studied, and ways to solve them are proposed. Particular attention is paid to the issue of decoupling of the power unit and control system. Various circuit solutions for building powerful MOSFET and IGBT transistor drivers are analyzed. Variants of galvanic isolation of power switches and master generator such as optical isolation, isolation by means of gate control transformers are investigated, as well as solutions on specialized chips with iCoupler technology are considered, their advantages and disadvantages are revealed. The analysis of the modern market of element base for practical realization of power part, drivers of transistors and control system is carried out. The issue of smooth start of powerful switching power supplies with transformerless input is investigated. The universal hardware modular platform of a high-frequency power supply is developed. Ways to improve the characteristics of the power supply by switching to software control with the ability to control operating parameters, their visualization and automatic software adjustment.

Purpose. Development of a comprehensive approach to the design of high-frequency switching power supplies for induction heating systems, taking into account the protection of transistors, smooth start and exit to the operating mode, opportunities for improvement by switching to software control.

Method. Methods of comparative analysis and experimental methods were used during the research.

Results. A universal hardware platform for switching power supply of induction heating installations and a comprehensive approach to its calculation have been developed.

Scientific novelty. For the first time, a comprehensive methodology for the development and calculation of full-bridge power supplies using modern advances in the electronics industry in the production of MOSFET and IGBT transistors, intelligent modules based on them, as well as individual gate drivers.

Practical importance. Debugging and testing of laboratory samples of low power induction heating installations.

Key words: transistor; driver; intelligent module; transformer; rectifier; IGBT; MOSFET.
\end{abstract}

Анотація. Проаналізовано принципи побудови джерел живлення установок індукційного нагріву. Розглянуто основні схемотехнічні рішення побудови силової частини, такі як мостовий та напівмостовий інвертор. Проведено огляд сучасного досвіду практичного виготовлення установок індукційного нагріву та їхніх джерел живлення. Досліджено основні проблеми, що виникають під час проєктування високочастотних джерел живлення на базі MOSFET- та IGBT-транзисторів, та запропоновано шляхи їх розв'язання. Особливу увагу приділено питанням розв'язки силової частини та системи керування. Проаналізовано різноманітні схемотехнічні рішення побудови драйверів потужних MOSFET- та IGBT-транзисторів. Досліджено варіанти реалізації гальванічної розв'язки силових ключів іа задаючого генератора, такі як оптична розв'язка, розв'язка за допомогою трансформаторів керування затворами, а також розглянуто рішення на спеціалізованих мікросхемах із 
технологією iCoupler, виявлено їхні переваги та хиби. Проведено аналіз сучасного ринку елементної бази для практичної реалізації силової частини, драйверів транзисторів і системи керування. Досліджено питання плавного запуску потужних імпульсних джерел живлення з безтрансформаторним входом. Розроблено універсальну апаратну модульну платформу високочастотного джерела живлення. Запропоновано шляхи поліпшення характеристик джерела живлення шляхом переходу на програмне керування 3 можливістю контролю параметрів роботи, їхньої візуалізації та автоматичного програмного корегування.

Мета. Розроблення комплексного підходу до проєктування високочастотних імпульсних джерел живлення установок індукційного нагріву з урахуванням питань захисту транзисторів, плавного запуску та виходу на робочий режим, можливостей удосконалення шляхом переходу на програмне керування.

Методика. Під час виконання дослідження використовувалися методи порівняльного аналізу та експериментальні методи.

Результати. Розроблено універсальну апаратну платформу імпульсного джерела живлення установок індукційного нагріву та комплексний підхід до їі розрахунку.

Наукова новизна. Уперше розроблено комплексну методику розроблення та розрахунку повномостових джерел живлення з використанням сучасних досягнень електронної промисловості у виробництві MOSFET- та IGBTтранзисторів, інтелектуальних модулів на їхній базі, а також окремих драйверів затворів.

Практична значимість. Налагодження та проведення випробувань лабораторних зразків установок індукційного нагріву малої потужності.

Ключові слова: транзистор; драйвер; інтелектуальний модуль; трансформатор; випрямляч; IGBT; MOSFET.

\section{ПОСТАНОВКА ЗАДАЧІ}

Індукційний нагрів широко використовується в різних технологіях обробки металів - від паяння і плавлення до термообробки та повторного нагріву.

Через індуктор під час індукційного нагрівання протікає змінний струм, що створює електромагнітне поле. Це поле наводить вихрові струми в заготівлі, яка може являти собою болванку, смугу, стрижень, сляб або стрічку. Вихрові струми викликають нагрів відповідно з ефектом Джоуля .

Отже, наявність ефективного, надійного джерела змінного струму або напруги є важливим фактором під час підбору обладнання для будь-якої технології індукційного нагріву [1].

Класично на невеликих частотах (до 10кГц) для установок індукційного нагріву використовувались інвертори на базі тиристорів, 3 розвитком сучасної силової електроніки з'явилася можливість як ключові елементи використовувати потужні IGBTта MOSFET-транзистори, завдяки цьому з'явилася можливість підняти частоти переключення вище за $100 \kappa Г ц$.

Промисловість серійно випускає установки індукційного нагріву 3 потужністю, яка вища за 10 кВт, для використання в технологічних процесах. Однак для лабораторних і наукових досліджень $\epsilon$ потреба в універсальних, широкорегульованих високочастотних джерелах живлення потужністю в одиниці кіловат. Готові прилади, які широко регулювалися б за напругою, частотою, шпаруватістю або могли працювати за заданими алгоритмами, серійно не випускають, тому постає питання розроблення таких пристроїв із використанням сучасних досягнень силової електроніки.

\section{АНАЛІЗ ОСТАННІХ ДОСЛІДЖЕНЬ І ПУБЛІКАЦІЙ}

Джерела живлення для індукційного нагріву $\epsilon$ перетворювачами частоти, які трансформують напругу трифазної мережі зі стандартною частотою в однофазну напругу (або струм) з частотою, необхідною для виконання конкретної технологічної операції індукційного нагріву. Випрямляч джерела живлення перетворює змінну мережеву напругу на постійну напругу, а інверторна або генераторна частина перетворює постійну напругу на однофазну змінну напругу необхідної для індукційного нагріву частоти.

Велика кількість типів і моделей джерел живлення розробляється так, щоб вони оптимально відповідали майже нескінченному різноманіттю потреб, що виникають під час індукційного нагрівання. Специфіка застосування індукційного нагріву в кожному конкретному випадку визначає частоту, потужність та інші параметри, такі як напруга, струм, коефіцієнт потужності або добротність. Графік сфер типового застосування індукційного нагріву залежно від частоти й необхідної потужності наведено на рис. 1 [2].

3 рисунка видно, що ніша малопотужних установок індукційного нагріву є незадіяною. У цій сфері працюють тільки ентузіасти та окремі дослідники. Аналіз публікацій за цією темою показує невелику кількість майже реалізованих проєктів. Великий внесок у розроблення та висвітлення можливих проблем, 3 якими може стикнутися розробник «бюджетних» варіантів лабораторних інверторів для індукційного нагріву, внесли С.В. Кухтецький (Інститут хімії та хімічної технології, СО РАН, м. Красноярськ), його публікації широко доступні в мережі Інтернет та активно обговорюються на форумах розробників силової електроніки [4-7]. 


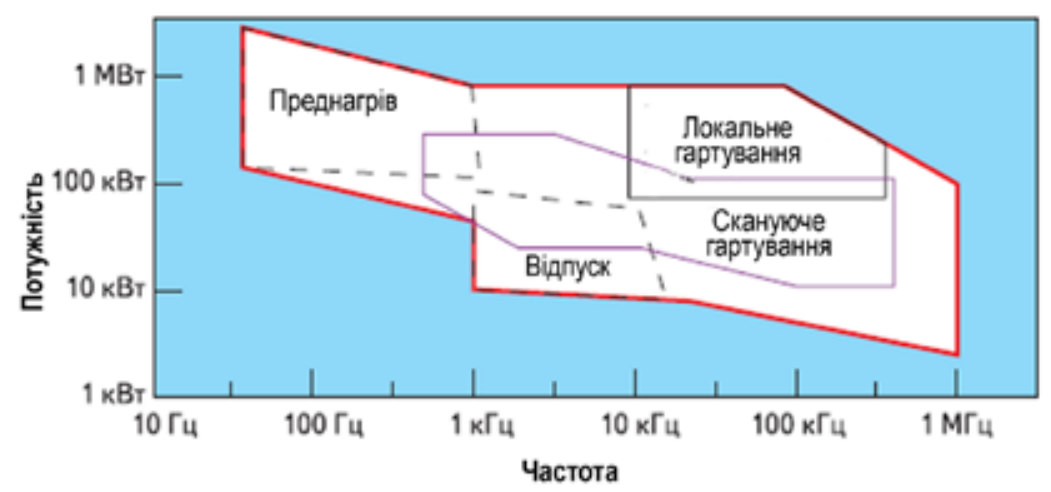

Рис. 1. Типові сфери застосування індукційного нагріву

\section{ВІДОКРЕМЛЕННЯ НЕ ВИРІШЕНИХ РАНІШЕ ЧАСТИН ЗАГАЛЬНОЇ ПРОБЛЕМИ}

Одним із головних завдань під час розроблення джерел живлення малопотужних установок індукційного нагріву є поєднання сучасних досягнень силової електроніки в сфері виробництва MOSFET- та IGBTтранзисторів, інтелектуальних модулів на їхній основі, окремих драйверів силових ключів 3 наявними схемотехнічними рішеннями в сфері високочастотних джерел живлення та їхніми методиками проєктування та розрахунку.

\section{МЕТА ДОСЛІДЖЕННЯ}

Розроблення комплексного підходу до проєктування високочастотних імпульсних джерел живлення установок індукційного нагріву з урахуванням питань захисту транзисторів, плавного запуску та виходу на робочий режим, можливостей удосконалення шляхом переходу на програмне керування.

\section{МЕТОДИ, ОБ'СКТ ТА ПРЕДМЕТ ДОСЛІДЖЕННЯ}

Методи дослідження - для розв'язання поставлених завдань використовуються методи порівняльного аналізу та експериментальні дослідження.

Об'єкт дослідження - лабораторний інвертор малопотужної установки індукційного нагріву.

Предмет дослідження - повномостовий інвертор на MOSFET-транзисторах та його система керування.

Проблема, що розв'язується, - розроблення комплексної методики розрахунку окремих елементів інвертора та його режимів роботи.

\section{ОСНОВНИЙ МАТЕРІАЛ}

Джерела живлення для індукційного нагріву в загальному випадку є перетворювачами частоти, які трансформують напругу трифазної мережі зі стандартною частотою в однофазну напругу (або струм) 3 частотою, необхідною для виконання конкретної технологічної операції індукційного нагріву. Хоча для їх позначення часто застосовують терміни «конвертор», «інвертор», «генератор», зазвичай джерела живлення є комбінацією цих пристроїв.

Конверторна частина джерела живлення перетворює змінну мережеву напругу (струм) на постійну напругу (струм), а інверторна або генераторна частина перетворює постійну напругу (струм) на однофазну змінну напругу (струм) необхідної для індукційного нагріву частоти.

Розуміння принципів функціонування різних схем джерел живлення, які використовуються для індукційного нагріву, необхідне під час вибору найкращої схеми для конкретного технологічного процесу або оцінки придатності іiі використання в конкретному процесі. Спрощену діаграму, що охоплює майже всі види джерел живлення, наведено на рис. 2 [8].

Найбільш поширеною конфігурацією інвертора $є$ мотова перетворювальна структура (рис. 3). Її часто називають міст «Н», оскільки вона складається 3 чотирьох плечей, які містять ключові елементи (тиристори або транзистори). Вихід розташовується на перекладині літери «Н» (діагональ моста), тож за розімкнутих ключів S1 i S2 струм тече справа наліво. Коли ключі S1 і S2 замкнуті, а ключі S3 i S4 розімкнуті, струм тече в протилежному напрямку - зліва направо. Оскільки цей процес повторюється, відбувається генерування змінного струму, частота якого визначається швидкістю перемикання вентилів.

Так званий напівмостовий інвертор складається тільки з двох ключових елементів і двох фільтрувальних конденсаторів. Вихідний ланцюг під'єднюється між загальними точками ключових елементів і конденсаторів, як це показано на рис. 3. Почергова комутація ключових елементів забезпечує протікання через вихідний ланцюг змінного струму.

Під'єднання джерела постійного струму (DC) видно 3 рис. 4. Ця конфігурація використовується замість мостової схеми, коли потрібні знижена вихідна напруга або вихідна потужність [9]. 


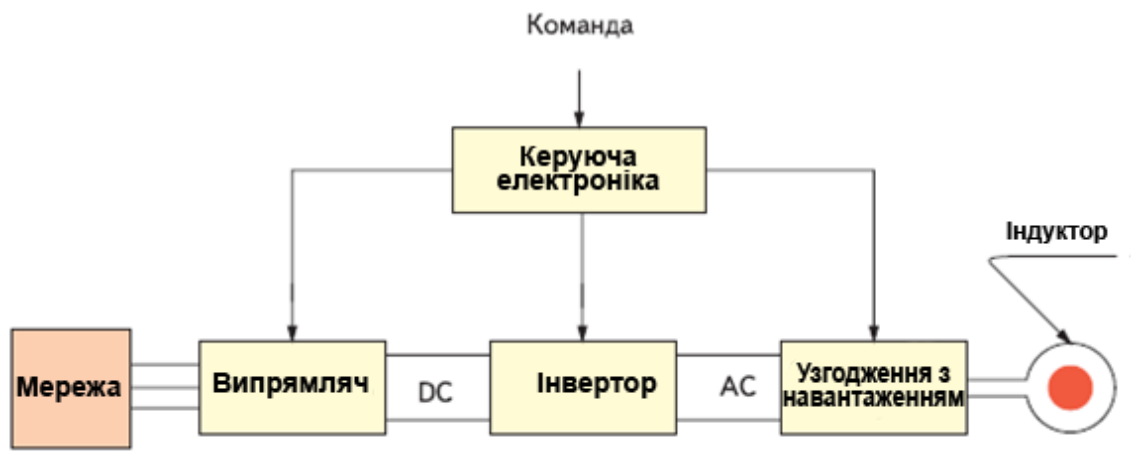

Рис. 2. Спрощена діаграма функціонування джерел живлення для індукційного нагріву

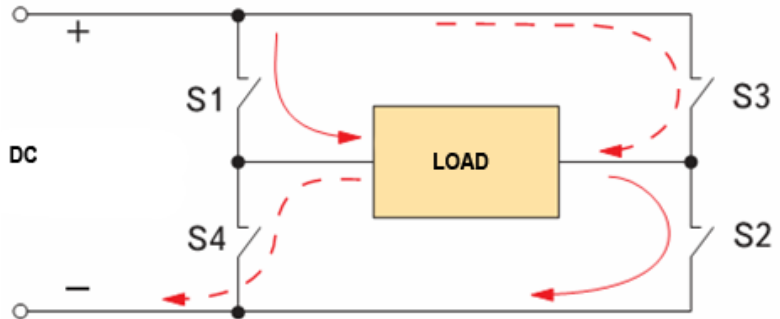

Рис. 3. Базова схема мостового інвертора

Вибір ключових транзисторів є непростим завданням. Важливими параметрами MOSFET-транзистора $\epsilon$ такі:

- тип корпусу;

- максимальна напруга стік-витік;

- струм стоку;

- опір у ввімкненому стані.

Напруга стік-витік не повинна перевищувати пробивної напруги, варто враховувати, що пробивна напруга за типової робочої температури $100-120^{\circ} \mathrm{C}$ приблизно на 7 \% вища за номінальну напругу.

Іншим критерієм вибору номіналу напруги MOSFET є стрибки перенапруги. Під час перехідних процесів вимкнення через паразитні індуктивності в ланцюзі напруга на стоці може досягти набагато вищих значень ніж у стаціонарному стані.

Усі ці критерії варто враховувати під час вибору номіналу напруги MOSFET. Максимальна стабільна напруга під час вимкнення не повинна перевищувати 70-90 \% від номінальної напруги.

У більшості застосувань MOSFET не виходить із ладу внаслідок перегріву за струмом через погані умови охолодження. Щоби зменшити втрати потужності зазвичай МОП-транзистори вибираються 3 низькими опорами постійного струму у ввімкненому стані та мають вищий номінальний струм, ніж потрібно в додатку. А втім, корисно перевірити безпечну робочу зону вибраного MOSFET.

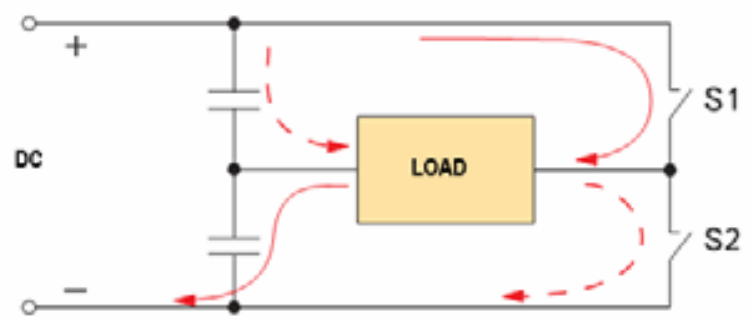

Рис. 4. Базова схема напівмостового інвертора

3 іншого боку, напруга джерела затвора повинна бути досить високою, щоб повністю ввімкнути MOSFET. Транзистор повинен мати можливість нести максимальний імпульсний струм у перетворювачі за будь-яких умов. Особливо під час запуску або короткого замикання на виході напруга живлення для IC управління може падати близько до межі блокувальної напруги. Деякі сучасні мікросхеми управління мають блокування низької напруги приблизно 7 В.

Найскладніший вибір полягає у виборі правильного за опором ввімкненого стану пристрою. Обмеженням для опору ввімкненого стану є максимально допустиме значення потужності розсіювання та максимальна температура переходу MOSFET.

Втрати потужності MOSFET можна розділити на втрати на провідність і втрати від перемикання. Втрати на провідність легко розрахувати через опір MOSFET і чітко визначений струм стоку.

Проблеми виникають під час обчислення втрат від перемикання MOSFET. Ці втрати сильно залежать від паразитарних параметрів. Найбільш достовірний спосіб визначення втрат потужності базується на вимірах енергії комутації в тестовій схемі, що працює на номінальному струмі.

Втрати енергії на провідність визначаються таким виразом:

$$
E_{\text {cond }}=\int_{0}^{t_{o n}} v_{d s}(t) \cdot i_{d}(t) d t=\int_{0}^{t_{o n}} R_{d s(O N)} \cdot i_{d}(t)^{2} d t,
$$




\section{ЕЛЕКТРОЕНЕРГЕТИКА, ЕЛЕКТРОТЕХНІКА ТА ЕЛЕКТРОМЕХАНІКА № 4 口 2020}

де $v_{d s}(t)$ - падіння напруги у ввімкненому стані;

$i_{d}(t)$ - залежність струму від часу в період ввімкненого стану транзистора.

Відповідно втрати потужності:

$$
P_{\text {cond }}=E_{\text {cond }} \cdot f \text {. }
$$

У зоні переривчастих струмів втрати потужності становлять:

$$
P_{\text {cond }}=E_{\text {cond }} \cdot f=\frac{1}{3} R_{d s(O N)} \cdot i_{\text {peak }}^{2} \cdot D .
$$

У зоні безперервних струмів втрати потужності становлять:

$$
P_{\text {cond }}=E_{\text {cond }} \cdot f=\frac{1}{3} R_{d s(O N)} \cdot D \cdot\left(i_{\text {min }}^{2}+i_{\text {peak }} \cdot i_{\text {min }}+i_{\text {peak }}^{2}\right) \text {. }
$$

Втрати енергії на перемикання діляться на втрати під час ввімкнення

$$
E_{o n}=\int_{0}^{t_{d(o n)}+t_{r}} v_{d s}(t) i_{d}(t) d t
$$

та втрати під час вимкнення:

$$
E_{\text {off }}=\int_{0}^{t_{d(o f f)^{+}}^{+t_{f}}} v_{d s}(t) i_{d}(t) d t .
$$

Загальні втрати потужності під час перемикання:

$$
P_{s w}=\left(E_{\text {on }}+E_{\text {off }}\right) \cdot f .
$$

Повна методика розрахунку втрат на перемикання описана в [10].

Наступним етапом розроблення є вибір схемної реалізації драйверів транзисторів.

У світі є велика кількість компаній, що пропонують готові ізольовані драйвери затворів MOSFET i IGBT, найбільш відомими з яких є ON Semiconductor, Infineon, Broadcom Limited, International Rectifier, Analog Devices, Toshiba Semiconductor, Vishay.

Головне завдання, яке розв'язує драйвер, - перетворення слабострумного логічного сигналу контролера на сигнал управління, чиєї потужності повинно вистачати для швидкої перезарядки ємностей ізольованого затвора. Крім того, оскільки силові ключі працюють за напруги, що істотно перевищує рівні сигналів контролера, драйвер повинен здійснювати гальванічну розв'язку вхідних імпульсів управління i затворних напруг. Гальванічна розв'язка необхідна в схемах, де потужний силовий каскад живиться мережевою напругою, а сигнали управління формуються контролером, зв'язаним із різними периферійними пристроями. Водночас ізоляція силової частини і схеми управління усуває комутаційні перешкоди й допомагає в екстремальних випадках захистити керівний контролер та інші логічні пристрої.

Основні параметри і вимоги, на підставі яких проводиться вибір типу драйвера, такі:
- пікове значення вихідного струму силових ключів і допустима розсіювана потужність перетворювача;

- конфігурація використовуваної схеми: одиночний ключ, драйвери верхнього і нижнього ключів (плечей) мостової схеми, драйвери верхнього і нижнього ключів із незалежним управлінням кожного $з$ них, напівмостові драйвери, які часто мають тільки один керівний вхід і можуть використовуватися для симетричного закону управління, драйвери управління всіма транзисторами мостової схеми і т. п.;

- необхідні функції захисту ключів;

- напруга ізоляції і т. д. [11].

Для надійної ізоляції сигналів під час управління затворами MOSFET i IGBT широке застосування знайшли оптоелектронні драйвери різних виробників. Оптоелектронні пари зарекомендували себе як незамінні елементи не тільки для гальванічної розв'язки, а й для придушення перешкод, що надходять через паразитні контури.

Структуру оптоелектронного драйвера наведено на рис. 5.

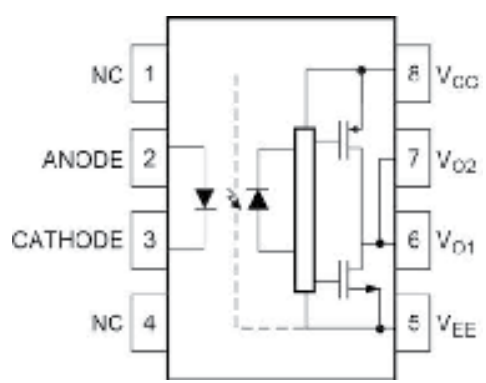

Рис. 5. Драйвер затвора FOD3184

Незважаючи на низку переваг, високовольтні драйвери затворів, виконані на основі оптронів, мають чимало обмежень. Це перш за все не найкращі часові характеристики:

- невисока швидкість перемикання, яка призводить до збільшення часу непродуктивної паузи («мертвого» часу), що зменшує загальну ефективність;

- затримки поширення сигналу перевищують $350 \mathrm{Hc}$;

- розкид часових характеристик різних компонентів однієї серії може перевищувати 200 нс;

- істотна різниця між часом наростання і спаду, іноді перевищує 100 нс.

Нарешті, найбільша вада пов'язана 3 утворенням ефекту замикання, коли короткочасні імпульсні перешкоди виходять за діапазон напруги живлення й можуть призводити до руйнування ізоляції p-nпереходу.

Цих хиб позбавлені ізольовані драйвери затворів MOSFET і IGBT, виконані на основі сучасної техно- 
логії цифрової гальванічної ізоляції iCoupler компанії Analog Devices.

Трансформатори iCoupler реалізовані безпосередньо на кристалі і являють собою планарні структури, виконані з CMOS-шарів і металізації золотом. Поліамідний шар із високою напругою пробою під шаром металізації ізолює верхню обмотку трансформатора від нижньої, завдяки чому забезпечується максимальна надійність і найбільший рівень ізоляції цифрових сигналів.

Ізольовані драйвери затворів компанії Analog Devices забезпечують гальванічну розв'язку за пікового вихідного струму до 4 А, високу швидкодію 3 максимальною затримкою поширення сигналів 55 нс і похибкою часового узгодження каналів менш ніж 5 нс, стійкість до синфазних перешкод 100 кВ/ мкс, а також термін служби не менш як 50 років за роботи в мережі змінного струму напругою 400 B (RMS) і в мережі постійного струму напругою до 1130 В [11].

Структурну схему мікросхеми драйвера показано на рис. 6.

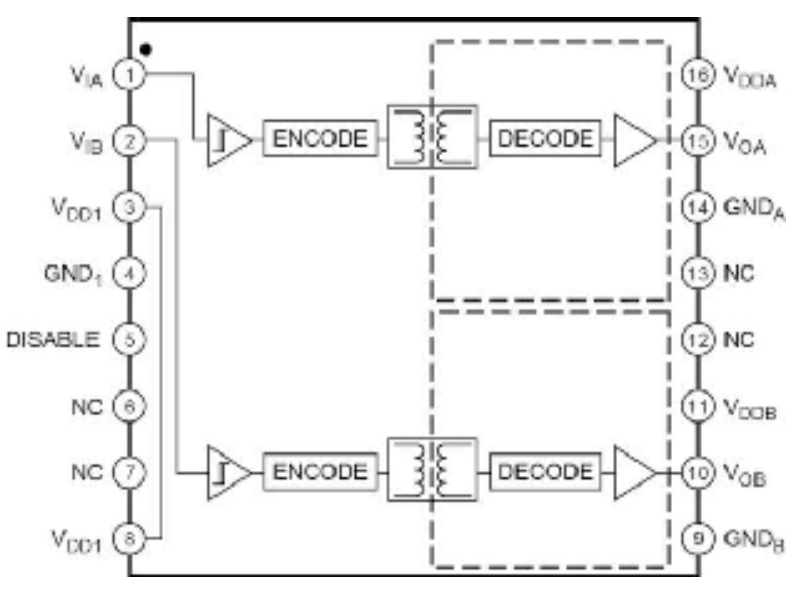

Рис. 6. Структурна схема мікросхем ADuM3223 i ADuM4223

За всіх своїх переваг ізольовані драйвери затворів MOSFET і IGBT, виконані на основі сучасної технології цифрової гальванічної ізоляції iCoupler, відрізняються досить високою ціною та важкодоступністю на внутрішньому ринку України. Для виготовлення дослідних зразків джерел живлення малопотужних установок індукційного нагріву можна використовувати одиничні трансформаторні драйвери затворів транзисторів (GDT), виконані методом біфілярної намотки на феритових кільцях.

Схему одного каналу керування драйвером транзистора наведено на рис. 7.

Смності конденсаторів для фільтрування постійного складника розраховуються за такими виразами:

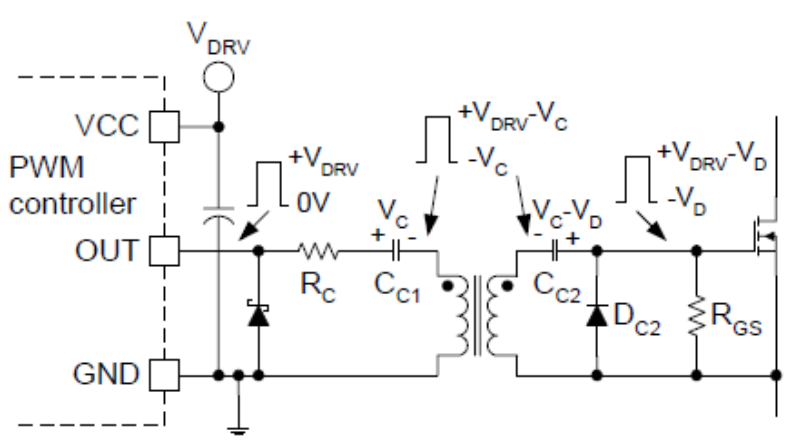

Рис. 7. Трансформаторний драйвер затвора

$$
\begin{gathered}
C_{C 1}=\frac{Q_{G}}{\Delta V_{C 1}}+\frac{\left(V_{D R V}-V_{D C 2, F W}\right) \cdot D}{\Delta V_{C 1} \cdot R_{G S} \cdot f_{D R V}}+\frac{V_{D R V} \cdot\left(D^{2}-D^{3}\right)}{\Delta V_{C 1} \cdot 4 \cdot L_{M} \cdot f_{D R V}^{2}}, \\
C_{C 2}=\frac{Q_{G}}{\Delta V_{C 2}}+\frac{\left(V_{D R V}-V_{D C 2, F W}\right) \cdot D_{M A X}}{\Delta V_{C 2} \cdot R_{G S} \cdot f_{D R V}}
\end{gathered}
$$

Для розрахунку кількості витків обмотки трансформатора використовується формула:

$$
N=\frac{V \cdot t}{B \cdot A e},
$$

де $\mathrm{N}$ - кількість витків, штук;

$\mathrm{V}$ - максимальна напруга на GDT протягом часу t, B;

$\mathrm{t}$ - час, за який буде подано напругу V, сек;

В - індукція насичення сердечника, Тл;

Ае - перетин сердечника, м² $^{2}$.

Кількість витків треба округлити в більший бік. Індукцію насичення варто вибирати з урахуванням прилеглих джерел магнітних полів.

За розробленою методикою було виготовлено дослідний зразок. Схемне рішення силової частини - повномостова схема на MOSFET-транзисторах; гальванічна розв'язка драйверів - одиничні трансформаторні драйвери затворів транзисторів (GDT), виконані методом біфілярної намотки на феритових кільцях; задаючий генератор на мікросхемі IR21531 з апаратним «мертвим часом» 0,6 мкс; робоча частота 20-100 кГц. На рис. 8 наведено осцилограму виходу задаючого генератора. На рисунку наведено два канали керування верхнім і ніжнім ключами, також наявний «мертвий час» перемикання транзисторів. На рис. 9 показано сигнал керування на затворі транзистора після виходу GDT. Видно, що за формою та рівнями сигнал повністю повторює сигнал задаючого генератора, це свідчить про правильний розрахунок параметрів GDT та його обв'язки. На рис. 10 показано осцилограму напруги на навантаженні. У сигналі наявні виплески напруги під час вимикання транзистора, що свідчить про необхідність корегування параметрів снаберних ланцюгів. 


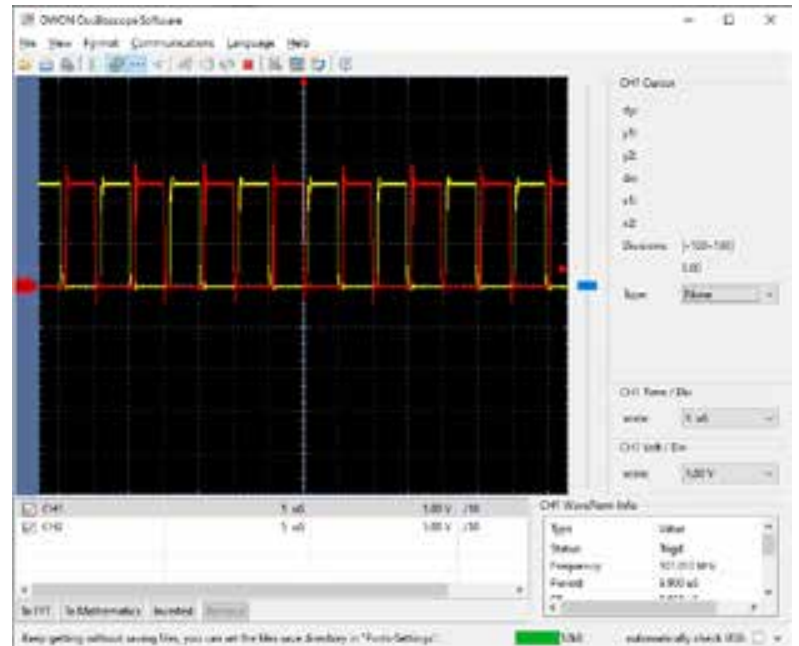

Рис. 8. Сигнали керування транзисторами на виході задаючого генератора

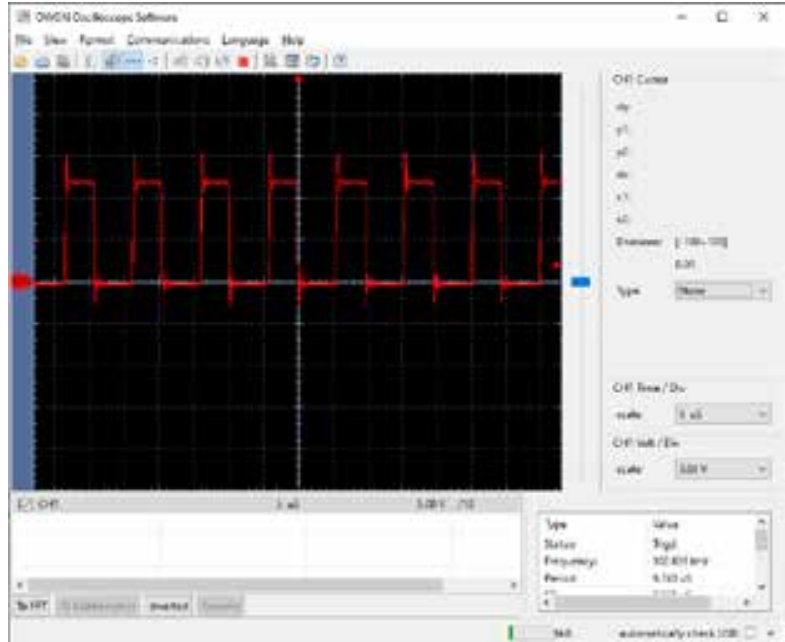

Рис. 9. Сигнали керування безпосередньо на затворі транзистора

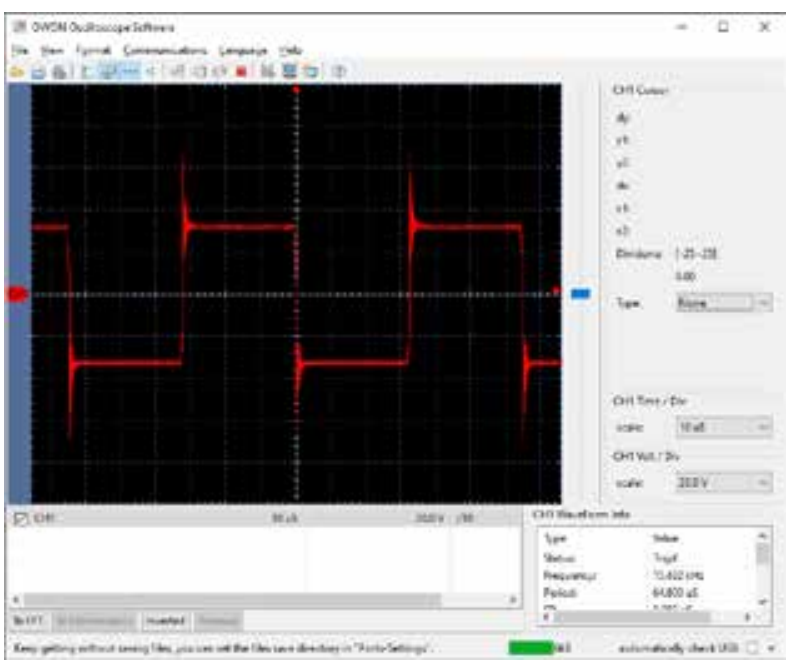

Рис. 10. Напруга на навантаженні

\section{ВИСНОВКИ}

Досліджено основні проблеми, що виникають під час проєктування високочастотних джерел живлення на базі MOSFET- та IGBT-транзисторів, та запропоновано шляхи їх розв'язання. Розроблено універсальну апаратну модульну платформу високочастотного джерела живлення. Розроблено комплексну методику розроблення та розрахунку повномостових джерел живлення 3 використанням сучасних досягнень електронної промисловості у виробництві MOSFETта IGBT-транзисторів, інтелектуальних модулів на їхній базі, а також окремих драйверів затворів.

\section{REFERENCES}

[1] Bolotovskij, Ju.I, Tanazly, G.I. (2007). Obzor poluprovodnikovyh istochnikov pitanija dlja indukcionnogo nagreva [Review of semiconductor power supplies for induction heating]. Silovaja Jelektronika, 4, 73-76. [in Russian].

[2] Bolotovskij, Ju.I, Tanazly, G.I., Rudnev, V.I., Don L. Lavless, Rjej L. Kuk (2007). Harakteristiki i parametry istochnikov pitanija dlja jeffektivnogo indukcionnogo nagreva [Characteristics and parameters of power supplies for efficient induction heating]. Silovaja Jelektronika, 1, 94-98. [in Russian].

[3] Kuhteckij, S.V. (2010). Prostoj laboratornyj invertor dlja indukcionnogo nagreva [Simple laboratory inverter for induction heating]. Retrieved from http://www.icct.ru/sites/default/files/Invertor-01.pdf [in Russian].

[4] Kuhteckij, S.V. (2010). Prostoj laboratornyj invertor dlja indukcionnogo nagreva: Chast' 2 [Simple laboratory inverter for induction heating: Part 2.]. Retrieved from http://www.icct.ru/sites/default/files/Invertor-02.pdf. 
[5] Kuhteckij, S.V. (2010). Cifrovoj moduljator plotnosti impul'sov dlja regulirovanija moshhnosti invertora [Digital pulse density modulator for regulating the power of the inverter]. Retrieved from http://www.icct.ru/sites/default/files/Invertor-03. pdf [in Russian].

[6] Kuhteckij, S.V. (2011). Sposoby podstrojki chastoty laboratornogo invertora [Methods for adjusting the frequency of a laboratory inverter]. Retrieved from http://www.icct.ru/sites/default/files/Invertor-04.pdf [in Russian].

[7] Kuhteckij, S.V. (2011). Laboratornyj invertor s PDM-regulirovaniem moshhnosti [Laboratory inverter with PDM power control.]. Retrieved from http://www.icct.ru/sites/default/files/Invertor-05.pdf [in Russian].

[8] Davydov, D.A., Ogurcov, K.N., Dunaeva, T.Ju. (2011). Istochniki pitanija ustanovok indukcionnogo nagreva [Power supplies for induction heating systems]. Saratov: Sarat. gos. tehn. un-t. [in Russian].

[9] Lebedev, A.V. (2007). Vybor istochnikov pitanija dlja indukcionnogo nagreva [Choice of power supplies for induction heating]. Silovaja jelektronika, 14, 1-7. [in Russian].

[10] Infineon Technologies AG (2002). How to Select the Right CoolMOSTM and its Power Handling Capability. Retrieved from https://www.infineon.com/dgdl/Infineon-ApplicationNote_MOSFET_CoolMOS_How_to_select_the_right_CoolMOS-ANv01_00-EN.pdf?fileId=db3a304412b407950112b40acf580693 [in Russian].

[11] Peskin, A. (2019) Obzor sovremennyh izolirovannyh drajverov zatvorov MOSFET/IGBT [An overview of modern isolated MOSFET / IGBT gate drivers]. Silovaja Jelektronika, 1, 10-20. [in Russian].

[12] Balogh, L. (2006) Design And Application Guide For High Speed MOSFET. Retrieved from http://www.radio-sensors.se/ download/gate-driver2.pdf

\section{СПИСОК ВИКОРИСТАНОЇ ЛІТЕРАТУРИ}

[1] Болотовский Ю.И., Таназлы Г.И. (2007). Обзор полупроводниковых источников питания для индукционного нагрева. Силовая электроника. № 4. С. 73-76.

[2] Болотовский Ю.И., Таназлы Г.И., Руднев В.И., Дон Л. Лавлесс, Рэй Л. Кук (2007). Характеристики и параметры источников питания для эффективного индукционного нагрева. Силовая электроника. № 1. С. 94-98.

[3] Кухтецкий C.B. (2010). Простой лабораторный инвертор для индукционного нагрева. URL: http://www.icct.ru/sites/ default/files/Invertor-01.pdf.

[4] Кухтецкий С.В. (2010). Простой лабораторный инвертор для индукционного нагрева: Часть 2. URL: http://www.icct.ru/sites/default/files/Invertor-02.pdf.

[5] Кухтецкий C.В. (2010). Цифровой модулятор плотности импульсов для регулирования мощности инвертора. URL: http://www.icct.ru/sites/default/files/Invertor-03.pdf.

[6] Кухтецкий С.В. (2011). Способы подстройки частоты лабораторного инвертора. URL: http://www.icct.ru/sites/default/ files/Invertor-04.pdf.

[7] Кухтецкий C.В. (2011). Лабораторный инвертор с PDM-регулированием мощности. URL: http://www.icct.ru/sites/ default/files/Invertor-05.pdf.

[8] Давыдов Д.А., Огурцов К.Н., Дунаева Т.Ю. (2011). Источники питания установок индукционного нагрева. Саратов : Сарат. гос. техн. ун-т.

[9] Лебедев А.В. (2007). Выбор источников питания для индукционного нагрева. Силовая электроника. № 14. С. 1-7.

[10] Infineon Technologies AG (2002). How to Select the Right CoolMOSTM and its Power Handling Capability. URL: https://www.infineon.com/dgdl/Infineon-ApplicationNote_MOSFET_CoolMOS_How_to_select_the_right_CoolMOSAN-v01_00-EN.pdf?fileId=db3a304412b407950112b40acf580693.

[11] Пескин А. (2019) Обзор современных изолированных драйверов затворов MOSFET/IGBT. Силовая электроника. № 1. C. $10-20$.

[12] Balogh L. (2006) Design And Application Guide For High Speed MOSFET. URL: http://www.radio-sensors.se/download/ gate-driver2.pdf.

(C) Д. В. Костенко, С. Л. Трибулькевич Дата надходження статті до редакції: 26.11 .2020 Дата затвердження статті до друку: 15.12.2020 